\title{
DE ESCRAVO A CABECEIRA: A TRAJETÓRIA DO AFRICANO JOÃO DE OLIVEIRA NO MUNDO ATLÂNTICO SETECENTISTA
}

\author{
Daniele Santos de Souza ${ }^{1}$
}

Resumo: Este artigo revisita a trajetória do africano liberto João de Oliveira, escravizado em Recife, no início do século XVIII, e que se tornou marinheiro a bordo de navios negreiros na rota entre a Bahia e a Costa da Mina, onde se fixou anos depois. Nesta região, segundo os traficantes da praça da Bahia, teria sido responsável pela abertura de Porto Novo e Onim para o comércio baiano. A experiência deste liberto é utilizada para compreender o tráfico transatlântico de africanos, mas também para analisar como este comércio, ao se disseminar pela sociedade, integrou as possibilidades de sobrevivência e afirmação da liberdade para alguns africanos libertos na Cidade da Bahia. Para isto, analisou-se, além do processo de devassa que João de Oliveira enfrentou ao retornar à Bahia, em 1770, fontes paroquiais, registros da Santa Casa de Misericórdia e do Tribunal da Relação.

Palavras-chave: tráfico de africanos, Costa da Mina, escravidão e liberdade.

\section{FROM SLAVE TO CABOCEER: THE TRAJECTORY OF THE AFRICAN JOÃO DE OLIVEIRA IN THE 18TH CENTURY ATLANTIC WORLD}

\begin{abstract}
This article revisits the trajectory of the freed African João de Oliveira, enslaved in Recife at the beginning of the 18th century, and who became a sailor aboard slave ships on the route between Bahia and Slave Coast, where he settled years later. In this region, according businessmen from Bahia, he would have been responsible for opening New Port and Onim for the Bahia's slave trade. The experience of this freedman is used to understand the trans-Atlantic slave trade between Bahia and Slave Coast, but also to analyze how this trade, as it spread through society, integrated the possibilities of survival and affirmation of freedom for some Africans freedmen in the City of Bahia. For this, it was analyzed, besides the inquiry process that João de Oliveira faced when he returned to Bahia, in 1770, parish sources and records from Santa Casa de Misericórdia and court cases of second instance.
\end{abstract}

Keywords: slave trade, Slave Coast, slavery and freedom.

\footnotetext{
${ }^{1}$ Doutora em História Social pela Universidade Federal da Bahia. Professora de História do Instituto Federal de Educação, Ciência e Tecnologia da Bahia. E-mail: daresouza@gmail.com
}

Revista da ABPN • v. 12, n. Ed. Especial - Caderno Temático: "Africanos, escravizados, libertos biografias, imagens e experiências atlânticas” • agosto de 2020, p. 113-139 
Resumen: Este artículo revisa la trayectoria del africano liberado João de Oliveira, esclavizado en Recife a principios del siglo XVIII, y que se convirtió en marinero a bordo de barcos esclavos en la ruta entre Bahía y la Costa da Mina, donde se instaló años después. En esta región, según empresarios de Bahía, habría sido responsable de abrir New Port y Onim para la trata de esclavos de Bahía. La experiencia de este liberto se utiliza para comprender el comercio transatlántico de esclavos entre Bahía y la Costa da Mina, pero también para analizar cómo este comercio, a medida que se extendió por la sociedad, integró las posibilidades de supervivencia y afirmación de libertad para algunos africanos libertos en el Ciudad de Bahía. Para esto, se analizó, además del proceso de investigación que João de Oliveira enfrentó cuando regresó a Bahía, en 1770, fuentes parroquiales y registros de Santa Casa de Misericórdia y casos judiciales de segunda instancia.

Palabras-clave: Tráfico africano, Costa da Mina, esclavitud y libertad

\section{DE L'ESCLAVE AU CAPITAINE: LA TRAJECTOIRE DU JOÃO DE OLIVEIRA AFRICAIN DANS LE MONDE ATLANTIQUE DU XVIIIE SIÈCLE}

Resumé: Cet article revient sur la trajectoire de l'Africain libéré João de Oliveira, asservi à Recife au début du XVIIIe siècle, et devenu marin à bord de navires négriers sur la route entre Bahia et la Côte des Esclaves, où il s'installe des années plus tard. Dans cette région, selon des hommes d'affaires de Bahia, il aurait été responsable de l'ouverture de New Port et Onim pour la traite négrière de Bahia. L'expérience de cet affranchi permet de comprendre la traite négrière transatlantique entre Bahia et la Côte des Esclaves, mais aussi d'analyser comment cette traite, en se répandant dans la société, a intégré les possibilités de survie et d'affirmation de liberté pour certains affranchis africains dans le Ville de Bahia. Pour cela, il a été analysé, outre le processus d'enquête auquel João de Oliveira a été confronté à son retour à Bahia, en 1770, des sources paroissiales et des archives de Santa Casa de Misericórdia et des affaires judiciaires de deuxième instance.

Mots-clés: Trafic africain, Côte des Esclaves, esclavage et liberté.

\section{INTRODUÇÃO}

Em dezembro de 1738, a galera $N^{a} S^{a}$ da Vida e Santo Antônio da Conceição aportou na Baía de Todos os Santos vinda da Costa da Mina com 585 escravizados à bordo. ${ }^{2}$ Além

\footnotetext{
${ }^{2}$ Arquivo Histórico Ultramarino, doravante AHU, ACL, CU, 005 Coleção Bahia Avulsos, Cx. 66, D. 5597, Carta do provedor da Alfândega da cidade da Bahia, Domingos da Costa de Almeida ao rei [D. João V] da relação do número de embarcações com suas invocações, nomes dos mestres que da Costa da Mina vieram a esta cidade e dos direitos que produziram os escravos despachados nesta alfândega, 8/10/1739. TransAtlantic Slave Trade Database, doravante TSTD. Trata-se de um banco de dados, coordenado por David Eltis e David Davidson, sobre os números do tráfico e as viagens negreiras através do Atlântico durante os

Revista da ABPN • v. 12, n. Ed. Especial - Caderno Temático: "Africanos, escravizados, libertos biografias, imagens e experiências atlânticas” • agosto de 2020,
} p. 113-139 
dos africanos no porão do navio, havia outros em meio à tripulação, uns escravos e alguns forros, entre eles o marinheiro mina João de Oliveira. A tripulação dos navios negreiros comumente era composta em parte por africanos e seus descendentes, fossem eles escravizados ou libertos, que realizavam as mais diversas atividades. Atuavam não apenas como marinheiros, mas também como carpinteiros, calafates, línguas (ou seja, tradutores ou intérpretes) e especialmente como barbeiros. ${ }^{3}$

A trajetória de João de Oliveira ganhou novos contornos quando ele decidiu registrar uma querela contra o capitão da referida galera, Pedro Gomes Caldeira, acusando-o de lhe ter açoitado nas nádegas durante a viagem, a despeito de ele ser forro. ${ }^{4}$ Surpreende a altivez de João de Oliveira em denunciar o ocorrido a bordo da embarcação em que trabalhava. A autoridade do capitão em alto mar era algo inquestionável, sendo a violência inerente ao mundo marítimo, em especial, ao tráfico negreiro. As sevícias, durante a travessia atlântica, distribuíam-se conforme a hierarquia da tripulação, que mesclava a diferenciação entre oficiais e demais tripulantes com distinções raciais. Deste modo, a violência se espraiava do oficialato branco para o resto da tripulação, com um requinte a mais a depender da cor da pele, descendo em cascata até os cativos, independentemente de eles pertencerem à carga ou à equipagem do navio. João Oliveira, no entanto, não considerou o ocorrido consigo como um episódio normal.

A querela aberta por este preto forro talvez seja uma ponta solta da trajetória, essa bem mais conhecida, de um liberto mina também chamado João de Oliveira que, entre os anos de 1750 e 1770, figurou como importante intermediário entre os negociantes da Bahia e os comerciantes e autoridades africanas na Costa da Mina. Este africano dizia ser "cabeceira e válido dos reis" nos diversos territórios e portos daquela costa. ${ }^{5}$ A trajetória dessa

séculos XVI ao XIX, disponível em: https://www.slavevoyages.org/. O número de identificação da viagem citada, assim como as demais localizadas neste banco, será referenciado da seguinte forma: \#51950.

${ }^{3}$ Sobre as tripulações dos navios negreiros ver: RODRIGUES (2005) e (2016); PETER LINEBAUG e REDICKER (2008); REDICKER (2011).

\footnotetext{
${ }^{4} \mathrm{~A}$ informação sobre esta querela é obtida através de uma provisão concedida por d. João $\mathrm{V}$ no âmbito do Tribunal da Relação da Bahia, em fevereiro de 1739, a Pedro Gomes Caldeira para que este pudesse embarcar novamente para a Costa da Mina e responder à acusação feita pelo preto João de Oliveira na Ouvidoria Geral do Crime por meio de um procurador. Ver: APEB, Seção Colonial/Provincial, Livro de Alvarás e Provisões do Tribunal da Relação, Maço 515, fl 218, Provisão concedida da Pedro Gomes Caldeira para responder por seu procurador, fevereiro de 1739.
}

${ }^{5}$ AHU, ACL, CU, 005-1 Bahia-Coleção Eduardo Castro e Almeida, Cx 44 D. 8244-8251. 21/05/1770 a 27/07/1770, Ofícios (2) o $1^{\circ}$, do governador, conde de Povolide, ao conde de Oeiras, sobre a apreensão e

Revista da ABPN • v. 12, n. Ed. Especial - Caderno Temático: "Africanos, 
personagem no tráfico negreiro emergiu na documentação quando ele decidiu encerrar suas atividades na Costa da Mina e passar seus últimos dias na Cidade da Bahia, como Salvador era conhecida à época. Ao retornar, acabou sendo preso, acusado de contrabando de tecidos. Sua prisão provocou uma devassa a pedido do provedor da alfândega, resultando, por sua vez, em um vasto processo. A análise da história de João de Oliveira, portanto, assim como a de muitos libertos no tempo da escravidão, foi possível graças a um processo judicial. ${ }^{6}$

As venturas e desventuras vividas por este liberto já foram narradas por diversos historiadores. ${ }^{7}$ A despeito disso, este artigo revisita sua trajetória com o objetivo de compreendê-la inserida não apenas no contexto do tráfico transatlântico de africanos entre a Bahia e a Costa da Mina. Propõem-se também analisar a experiência de João de Oliveira buscando entender como a rede mercantil demandada pelo comércio negreiro tornou-se parte das estratégias de sobrevivência de alguns libertos africanos na Bahia colonial.

A prisão de João de Oliveira, ocorrida pouco depois do seu desembarque, decorreu de ação policial do então governador da Capitania da Bahia, Luiz José da Cunha Grã Ataíde e Melo, o conde de Povolide, que se empenhou no combate ao contrabando de tecidos europeus no porto de Salvador, vindos, em grande medida, da Costa da Mina. Ao ser preso, o africano apelou para a rede de relações que havia construído durante décadas: os principais traficantes de escravos da praça da Bahia. Esses homens atestaram os préstimos que o "cabeceira" havia realizado em prol dos interesses portugueses nos portos

despacho de fazendas levadas à Bahia, pelos navios que faziam o comércio da Costa da Mina, o $2^{\circ}$, do provedor da Alfândega, Rodrigo da Costa de Almeida, sobre a remessa da devassa relativa ao contrabando de fazendas provenientes da Costa da Mina, a prisão de João de Oliveira, e o sequestro dos seus bens. Atestado de comerciantes da Bahia fazendo exposição dos serviços prestados pelo preto João de Oliveira para o comércio da Costa da Mina. Requerimento do preto João de Oliveira, solicitando restituição de escravos e bens. Termo de avaliação, obrigação e entrega dos bens sequestrados do preto João de Oliveira. Autos de devassa dos extravios e contrabando feito na chegada da corveta Nossa Senhora da Conceição e Almas, do capitão Manuel de Souza Coelho, do senhorio Jacinto José Coelho, que tinha vindo da Costa da Mina. Auto do sequestro dos bens do preto João de Oliveira, e Manuel de Souza Coelho. Auto de perguntas feitas ao preso João de Oliveira. Quase todas as informações sobre a trajetória do africano João de Oliveira mencionadas neste trabalho provêm desse conjunto documental, quando do contrário, a fonte será referenciada.

6 Outros exemplos de trajetórias de africanos no período da escravidão cujas informações advém principalmente da documentação referente à repressão das autoridades governamentais são: REIS, GOMES e CARVALHO (2010); REIS (2008); REIS, (2008); SAMPAIO (2009).

${ }^{7}$ Entre os estudiosos que analisaram a trajetória de João de Oliveira destacam-se: VERGER, (1987, p. 211, 264, 527-528, 539-340) e (1992, pp. 101-106); SILVA (2003, pp. 119, 124, 160) e (2004, pp. 23-24, 35-36, 63 e 119); RIBEIRO, (2005, pp. 67-68); LAW e MANN, (1999, pp. 307-334). LESSA, (1957, p. 196.); HICKS, (2019); SOUZA, (2013, pp. 1-23). Este último, diferente dos demais autores, buscou analisar aspectos religiosos da trajetória de João de Oliveira, especialmente sua relação com o catolicismo e as irmandades negras.

Revista da ABPN • v. 12, n. Ed. Especial - Caderno Temático: "Africanos, escravizados, libertos biografias, imagens e experiências atlânticas” • agosto de 2020, p. 113-139 
da Costa da Mina. O termo "cabeceira" faz alusão a "cabeça", capitão, principal, ou seja, tratava-se do chefe representante da autoridade régia africana sobre o comércio atlântico, sendo um cargo encontrado em alguns portos do tráfico negreiro (SPARKS, 2014 e 2020). João de Oliveira era cabeceira em Porto Novo e negociava a abertura de Onim, futura Lagos, para o tráfico baiano. . O liberto fez questão de ressaltar tais préstimos quando encaminhou sua petição ao rei d. José e ao marquês de Pombal, utilizando a linguagem da reciprocidade para solicitar a sua soltura e restituição de seus bens, além de apresentar alguns detalhes sobre sua vida.

A literatura que trata da trajetória deste personagem tem como base a análise do processo resultante de sua prisão. Este artigo, por meio do cruzamento de fontes paroquiais e documentos da Santa Casa de Misericórdia, busca caminhar um pouco mais. Cogita-se que João de Oliveira, após o desembarque na Cidade da Bahia, em 1770, não encerrou sua carreira no tráfico, manteve negócios diretamente na Costa da Mina ou junto a proprietários, armadores ou capitães de navio negreiro, adquirindo escravos para seu uso e/ou revenda até quase o final da década de 1770.

A participação deste liberto no tráfico transatlântico, conforme relatado no ofício encaminhado por ele ao rei de Portugal, teria se iniciado por volta da década de 1730, na Costa da Mina. Embora não tivesse citado exatamente em qual porto, levando em consideração este espaço temporal, é possível que o local escolhido para dar início a seus negócios fosse Ajudá ou Apa. No primeiro existia uma feitoria portuguesa, enquanto o segundo havia se tornado um importante enclave de comércio europeu após a devastação de Jaquim pelo rei daomeano, em $1732 .^{8}$. O expansionismo do Daomé, na década de 1720 , mudou a configuração política na Costa da Mina e ocasionou, com o avançar do século XVIII, um decréscimo no tráfico em Ajudá. Este entreposto passou a enfrentar, nas décadas seguintes, uma forte competição tanto de portos a oeste, como Popo Grande e Pequeno, quanto a leste, onde se encontravam Badagri, Apa, Epe, Porto Novo e Lagos (tendo os dois últimos emergidos a partir da segunda metade do século XVIII). Estes novos locais de tráfico negreiro, a leste de Ajudá, surgiram no esteio das ações militares do rei daomeano Agaja,

\footnotetext{
${ }^{8} \mathrm{O}$ rei do Daomé, Agaja, enviou uma ofensiva militar a Jaquim em 1732, destruindo a feitoria portuguesa. O entreposto, no entanto, foi recuperado e continuou funcionando até o início da década seguinte. Cf. VERGER (1987, pp. 167-171); LAW (1997, pp. 175, 222-223; 1991, pp. 17, 140-141, 295-297.; 2004, pp. 21, 46-52).
}

Revista da ABPN • v. 12, n. Ed. Especial - Caderno Temático: "Africanos, escravizados, libertos biografias, imagens e experiências atlânticas” • agosto de 2020, p. 113-139 
sendo formados por refugiados e exilados dos reinos de Aladá, Weme e Hueda e acompanharam a expansão do comércio atlântico (LAW, 2004, p. 125).

Figura 1: MAPA 1 - COSTA DA MINA

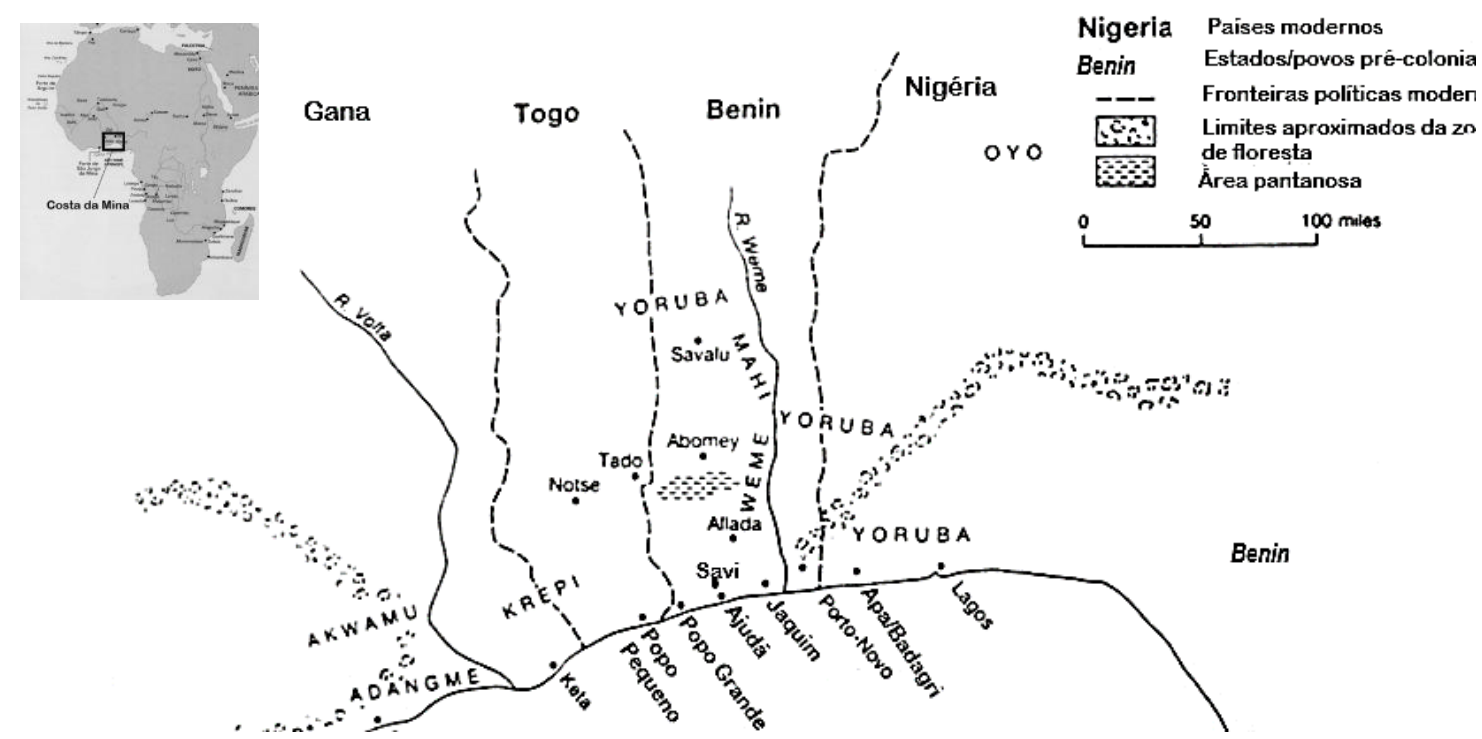

Fonte: LAW, Robin. The Slave Coast of West África 1550-1750. The Impact of the Atlantic Slave on an African Society, Oxford: Clarendon Press: 1991, p.18, (adaptado).

Quando João de Oliveira desembarcou em um dos portos da Costa da Mina, por volta de 1733, certamente presenciou ou teve notícias sobre estes conflitos. (LAW 1991, pp. 299341 e 2004, p. 63). Quiçá tivesse presenciado o ataque daomeano ao porto de Epe, em 1747, tendo em vista que muitos navios da Bahia passaram a frequentá-lo como alternativa a Ajudá. Através de Epe, os exilados de Aladá exportavam os cativos adquiridos por meio das redes comerciais do interior. A invasão do Daomé levou-os a estabelecerem um novo local para o tráfico transatlântico, Porto Novo, onde o comércio negreiro passou a ser realizado a partir de 1750. (AKINJOGBIN, 1967, p. 128; LAW, 1991, pp. 314-315 e 2004, p. 126). Provavelmente, foi junto às autoridades do novo reino de Aladá que João de Oliveira iniciou as tratativas que o levaram a se tornar cabeceira junto aos chefes africanos e intermediário dos capitães portugueses, abrindo Porto Novo para o tráfico baiano.

Em meados do Setecentos, chegaram à Costa da Mina notícias da Bahia que impactaram diretamente os negócios de João de Oliveira, tratava-se da provisão régia de 1756. Esta provisão tornou livre o tráfico baiano nesta região africana, pondo fim ao

Revista da ABPN • v. 12, n. Ed. Especial - Caderno Temático: "Africanos, escravizados, libertos biografias, imagens e experiências atlânticas” • agosto de 2020, p. $113-139$ 
monopólio das 24 embarcações, pertencentes a apenas quinze proprietários. No bojo dessas medidas, a que maior alcance teve sobre os interesses de João de Oliveira foi a determinação de que apenas uma embarcação portuguesa por vez poderia adentrar ao porto de Ajudá. Isto estimulou ainda mais a navegação dos vasos baianos para os portos à leste, ou seja, para Porto Novo e Badagri, onde havia oferta segura de cativos, sem a demora recorrente do porto daomeano. A morosidade no abastecimento de navios negreiros em Ajudá relacionava-se não apenas com o cumprimento da provisão de 1756, mas também pelas dificuldades daomeanas em estabelecer redes seguras de fornecimento de escravizados. ${ }^{9}$ Neste momento, Oliveira já acessava as redes mercantis do tráfico ligadas tanto aos comerciantes de Oyó quanto aos traficantes da Bahia, bem como usufruía de boas relações com as autoridades de Porto Novo, onde havia construído um ancoradouro. Esse equipamento foi fundamental para a inserção e proteção dos navios oriundos da Bahia. Assim, em pouco tempo, sua influência na costa africana o fez importante para o comércio negreiro baiano, tornando-o conhecido e apreciado pelos traficantes sediados em Salvador.

\section{DA VIDA NA ESCRAVIDÃO PARA A ESCRAVIDÃO COMO MEIO DE VIDA}

O encarceramento de João de Oliveira produziu um volume significativo de documentos. Além do requerimento no qual ele narrou a sua história e o atestado dos negociantes da Bahia confirmando os bons serviços prestados por ele na Costa da Mina, há um ofício do governador da capitania da Bahia - Luiz José da Cunha Grã Ataíde e Melo, o conde de Povolide -, a devassa executada pelo provedor da alfândega e o termo de avaliação dos bens do liberto, sequestrados na ocasião da sua prisão. É principalmente com base nos dois primeiros documentos que se conhece a atuação de João de Oliveira na costa africana.

O africano contou ser "natural do gentio da Costa da Mina" e teria sido "apreendido pelos seus naturais de menor de idade", vendido e embarcado para Pernambuco. Não

\footnotetext{
${ }^{9}$ A escassez de escravos em Ajudá também estava relacionada com a forma que os monarcas administravam o comércio negreiro. Os reis daomeanos colocavam-se como intermediários do tráfico transatlântico de maneira muito mais impositiva em comparação aos de Aladá e Hueda, na época em que esses reinos controlavam os portos de Jaquim e Ajudá. Os comerciantes que dominavam as redes de abastecimento de escravos no interior eram obrigados a venderem seus cativos aos mercadores do Daomé. Isto porque, não lhes era permitido comercializar diretamente com os europeus na costa. Além disso, o Estado daomeano proibia os comerciantes estrangeiros de adquirirem mercadorias de caráter militar como armas de fogo, pólvora e barras de ferro. Cf. AKINJOGBIN, (1967, pp.148-149).
}

Revista da ABPN • v. 12, n. Ed. Especial - Caderno Temático: "Africanos, escravizados, libertos biografias, imagens e experiências atlânticas” • agosto de 2020, p. $113-139$ 
mencionou o nome de seu país ou qualquer etnônimo que revelasse sua origem com maior precisão. Talvez, porque se tratasse de um documento endereçado ao rei de Portugal, no qual seria inconveniente ou desnecessária tal informação. Pode-se supor também que, após tantos anos de envolvimento com o comércio transatlântico e de ter vivenciado a escravidão no Brasil, tivesse absorvido a definição identitária "gentio da Costa da Mina", construída pelo tráfico. Estima-se que João de Oliveira tivesse nascido em um dos reinos do Golfo do Benim nos últimos anos do século XVII ou logo no começo da centúria seguinte, visto que, ao retornar à Cidade da Bahia, em 1770, afirmara ter 70 anos "pouco mais ou menos", havendo sido escravizado em "menor idade".

O único indício sobre a possível origem étnica de João de Oliveira encontra-se no seu termo de prisão. Ao descrever os traços físicos do liberto, o escrivão mencionou que este possuía "três sinais de cada feixe em cada uma das faces do rosto feitos na tua terra". Verger sugere se tratar das abadja meta, marca característica dos africanos de língua posteriormente denominada iorubá. Reis supõe que, sendo uma abadja meta, se refira a um indivíduo oriundo de Oyó, onde os súditos recebiam esta marca para evitarem ser escravizados, embora Oliveira, por alguma razão, não tivesse escapado dessa tragédia. (VERGER, 1992 p. 9; REIS, 2003). Uma provável origem iorubá ajudaria a entender a ida de Oliveira para os portos a leste de Ajudá, principalmente para Porto Novo. Este enclave tornou-se, ao longo da segunda metade do XVIII, o principal exportador dos cativos comercializados por Oyó. de quem era tributário, abrigando uma significativa comunidade de comerciantes daquela região, embora o porto pertencesse ao novo reino de Aladá. Certamente, a familiaridade com os costumes e a língua - tanto a iorubá quanto a portuguesa - contribuíram para que João de Oliveira obtivesse a confiança do rei - a ponto deste o tornar cabeceira e autorizar a construção de um ancoradouro - bem como a simpatia dos negociantes de escravos africanos e europeus.

O cabeceira não ofereceu detalhes sobre as circunstâncias da sua captura, escravização e venda na costa da África. De certo um episódio dramático que não cabia, naquele momento, relembrar. Para o liberto o mais importante foi ressaltar os serviços prestados aos negociantes de origem portuguesa. O conde de Povolide, por sua vez, em ofício enviado ao rei d. José, não deixou de salientar ser o cabeceira "o maior favorecedor da nação portuguesa na Costa da Mina”. Grandes traficantes da Cidade da Bahia, entre eles Antônio Cardoso dos Santos e David de Oliveira Lopes, destacaram que o liberto,

Revista da ABPN • v. 12, n. Ed. Especial - Caderno Temático: "Africanos, escravizados, libertos biografias, imagens e experiências atlânticas" • agosto de 2020, p. $113-139$ 
em diversos momentos, auxiliou os navios baianos e pernambucanos, "sustentando a sua custa em algumas ocasiões várias guerras". O cabeceira buscava evitar, deste modo, os "prejuízos e roubos" tão comumente vivenciados pelas embarcações lusitanas naquela costa.

Paralelo a isto, João de Oliveira buscou estreitar laços comerciais com o reino de Benin, objetivando abrir o porto de Onim para o tráfico baiano. Capitães negreiros da Bahia já frequentavam esse ancoradouro desde a década de 1760. De acordo com o capitão-mor e ouvidor de São Tomé e Príncipe, Vicente Gomes Ferreira, entre 1766 e 1769, quatro embarcações negreiras, que aportaram nas ilhas em direção a Salvador, tiveram Onim como seu porto principal para aquisição de cativos. ${ }^{10}$ João de Oliveira chegou a trazer consigo, em 1770, dois embaixadores de Onim para negociarem com o governador da Bahia. Porém, as tratativas foram malogradas com a prisão do cabeceira, quando houve o sequestro de seus bens. Nesta ocasião, os emissários do rei africano, por serem pretos, acabaram sendo arrolados junto com os escravos pertencentes ao liberto, como se cativos fossem sendo todos enviados para a cadeia pública. A despeito do fracasso da embaixada que acompanhava João de Oliveira, a partir de 1790, Onim se tornaria um importante porto do comércio baiano na Costa da Mina e, durante a fase ilegal deste negócio, de 1815 em diante - pois o porto estava acima da linha do Equador - passaria a ser o principal fornecedor de cativos até a extinção do tráfico em 1850 (VERGER, 1992, pp. 9-13; LAW e MANN, 1999, pp. 307-334).

Portanto, João de Oliveira, ao se inserir como importante negociante de escravos em Porto Novo e Onim, nada mais fez que aproveitar as oportunidades comerciais abertas pelo contexto político na Baía de Benin. O cabeceira garantia a segurança do comércio português em Porto Novo, auxiliava as embarcações a "efetuarem o seu negócio com mais brevidade", evitando "a mora e a corrupção", bem como a "perda a que naquele clima está exposto o mesmo tabaco". O liberto chegava a dispor, inclusive, de uma milícia própria para assegurar os seus negócios, pois afirmou em seu requerimento ter livrado "por muitas vezes com as

\footnotetext{
${ }^{10}$ AHU, ACL, CU, 070 São Tomé, Cx 12 D. 28, Relação dos navios portugueses e estrangeiros que entraram na Ilha de São Tomé durante dez anos de 1759-1770, 04/11/1770. AHU, ACL, CU, 070 São Tomé, Cx 12 D.30, Relação dos navios portugueses e estrangeiros que entraram na Ilha do Príncipe entre 1758-1763, 04/11/1770. AHU, ACL, CU, 070 São Tomé, Cx 13 D. 2, Relação dos navios portugueses que entraram na barra de São Tomé e Príncipe entre 1760-1771, contendo o nome dos navios, seus capitães e a quantidade de cativos que transportavam, 24/01/1771.
}

Revista da ABPN • v. 12, n. Ed. Especial - Caderno Temático: "Africanos, escravizados, libertos biografias, imagens e experiências atlânticas” • agosto de 2020, p. 113-139 
suas forçaa" os capitães "dos assaltos e roubos que os mesmos reis lhe mandavam fazer por quadrilhas do gentio". No ano de 1765, por exemplo, época em que Oliveira estava diretamente envolvido no tráfico na costa africana, Porto Novo foi responsável por exportar 1200 escravos, mais que Epe e Badagri juntos.( AKINJOGBIN, 1967, p.140).

Ao retornar à Cidade da Bahia, João de Oliveira alegou que desejava passar o resto dos seus dias em terras católicas. Dizia ter contribuído com "as obras da capela mor da Igreja de $N^{a} S^{a}$ da Conceição dos Militares", no Recife, por ser esta a sua santa de devoção. Entre os 122 escravos que trouxe, dois homens e duas mulheres foram destinados como esmola a esta igreja e o liberto fez questão de ressaltar que já havia auxiliado com outras doações algumas irmandades de Salvador. ${ }^{11}$ Àquela altura, em 1770, João de Oliveira trazia consigo a expertise de quem dominava praticamente todas as etapas do comércio negreiro, da escravização no continente africano à venda no Brasil, fosse como cabeceira ou mesmo por experiência própria enquanto escravizado. Sabia atuar como intermediário nas redes do tráfico no interior da África, negociava com os reis locais e com os capitães europeus e conhecia muito bem as operações relacionadas ao transporte da carga humana até os portos das Américas. Ademais, tinha noção de como se daria o processo de venda dos cativos após o desembarque e sabia perfeitamente o destino que os esperava. Tudo isto porque, além da experiência da escravidão, antes de "militar como cabeceira" exerceu o ofício de marinheiro em embarcações negreiras.

\section{ATRAVÉS DO ATLÂNTICO: O ENCONTRO COM A ESCRAVIDÃO E A}

\section{LIBERDADE}

\footnotetext{
${ }^{11}$ Em 1725, os soldados do Terço do Recife, reunidos em uma irmandade, solicitaram a d. João V ajuda de custo e renda anual para construção e conservação de uma igreja em devoção à $N^{a} S^{a}$ da Conceição. Estavam também envolvidos nessa empreitada os sargentos e soldados do Terço de Henrique Dias (corpo militar formado por libertos africanos e crioulos), em cuja igreja pretendiam poder ser sepultados. João de Oliveira, certamente, ainda residia no Recife nessa época, quiçá, na freguesia de Santo Antônio, onde a igreja fora erguida e, ao que parece, mantinha relações com membros do Terço e da irmandade. As obras da igreja somente foram concluídas em 1771. De modo que os dois cativos que João de Oliveira enviou como esmola, provavelmente foram de grande valia para a irmandade. Ver: AHU, ACL, CU, 015 Coleção Pernambuco Avulsos, Cx. 31, D. 2802, Requerimento dos soldados do Terço do Recife ao rei [D. João V], pedindo ajuda de custo e renda anual para construção e conservação da igreja de sua irmandade, dedicada à Nossa Senhora da Conceição, 19/03/1725. AHU, ACL, CU, 015 Coleção Pernambuco Avulsos, Cx. 34, D. 3143, Carta do provedor da Fazenda Real da capitania de Pernambuco, João do Rego Barros, ao rei [D. João V], sobre o requerimento dos sargentos e soldados do Terço de Henrique Dias informando o estado da obra que principiaram da Igreja de Nossa Senhora da Conceição para nela serem sepultados, 13/09/1726.
}

Revista da ABPN • v. 12, n. Ed. Especial - Caderno Temático: "Africanos, escravizados, libertos biografias, imagens e experiências atlânticas” • agosto de 2020, p. 113-139 
No Recife, João de Oliveira foi escravo de um negociante com relações mercantis na Cidade da Bahia, para onde acabou sendo enviado para servir como marinheiro na carreira da Costa da Mina. O liberto não revela ao certo quanto tempo atuou neste ofício. Sua narrativa é dúbia com relação a isto, pois disse ter voltado à Costa da Mina "em um navio dos desta praça [Bahia], em cuja ocasião se ficou entre os seus naturais”. De modo não ser possível determinar se teria se estabelecido na África já na primeira viagem. Acredito, no entanto, que dificilmente João Oliveira conseguiria se inserir na comunidade mercantil de um porto negreiro sem conhecer previamente os costumes e as práticas de comércio que norteavam as relações entre africanos e europeus. Conhecimento este impossível de se adquirir em uma única viagem. Ademais, não se pode descartar a possibilidade de ele ter sido, inicialmente, auxiliar de algum mercador na costa africana, talvez do próprio senhor, quando teria aprendido os trâmites do negócio.

A narrativa em torno da compra da sua alforria também traz ambiguidades. O liberto deixa implícito que foi através do tráfico transatlântico de africanos que obteve o pecúlio necessário para conquistar sua liberdade, embora não mencionou quanto the custou nem como foi feito este pagamento. Porém, não fica evidente se a transação foi concluída após ele ter se instalado na Costa da Mina ou enquanto atuava nesta carreira marítima. Trabalhado a bordo de navios negreiros, João de Oliveira, como muitos tripulantes dos tumbeiros, talvez tenha aproveitado para investir em algumas mercadorias, como rolos de tabaco, açúcar ou boiões de doce, visando adquirir, diretamente na África, alguns cativos para si. Deste modo, poderia obter a alforria por substituição - algo comum na escravidão brasileira durante a era do tráfico -, vendê-lo no mercado de Salvador ou quiçá pô-los ao ganho. Situações que o teriam tornado, por certo período, um escravo dono de escravos. ${ }^{12}$

O envolvimento de João de Oliveira com o tráfico e a escravidão extrapola a trágica ironia de ele ter conseguido pagar pela sua alforria com os recursos obtidos pelo mesmo comércio que outrora havia subtraído a sua "nativa liberdade". No requerimento encaminhado à Sua Majestade, o liberto reconheceu, como um "verdadeiro cristão [...] o direito que pela compra em boa-fé fizeram dele suplicante, em Pernambuco, seus patronos" ${ }^{13}$ Por certo, o cabeceira enfatizou isso propositalmente, desejando evidenciar que

\footnotetext{
${ }^{12}$ Sobre este fenômeno ver: ALMEIDA (2018); COSTA (2013); REIS (2013; 2014; 2016); SOUZA (2018).

${ }^{13} \mathrm{O}$ requerimento de João de Oliveira integra o processo no qual foi preso e as menções seguintes referem-se a este documento. Ver AHU, ACL, CU, 005-1 Bahia - Coleção Eduardo Castro e Almeida, Cx 44 D. 8246. do negro

Revista da ABPN • v. 12, n. Ed. Especial - Caderno Temático: "Africanos, 
mesmo fora do alcance senhorial, em plena costa africana ou no decurso das viagens, não deixou de reconhecer, no melhor estilo do direito português, a legitimidade da propriedade de seu senhor sobre ele. Por isso, mandou restituir o "valor para sua libertura" [sic] deixando dúbio se havia fugido para Costa da Mina ou ali permanecido com autorização senhorial. Talvez, para não suscitar questionamentos sobre esses detalhes, enfatizou ter abraçado os costumes do mundo dos brancos, distinguindo-se do paganismo da costa, ao afirmar que, mesmo "entre os seus naturais", conservava-se "na pureza da fé católica". Ou seja, sua cristandade era ratificada tanto pelo sacramento do batismo quanto pelo reconhecimento da escravidão como instituição legítima. "Como verdadeiro cristão" na costa africana, João de Oliveira era dono de escravos, logo buscava legitimar o tráfico e a escravidão que atravessou a sua vida, mas da qual ascendera de vítima a beneficiário (SOUZA, 2013, pp.1-23).

O cabeceira também fez questão de destacar, no mesmo requerimento, que, enquanto liberto, comportou-se da forma esperada pela sociedade escravista colonial. Ou seja, demonstrou gratidão por seus antigos senhores, conforme determinavam as ordenações filipinas, "lembrando da criação, e doutrina cristã, que lhe ensinaram". ${ }^{14}$ Assim, ao ter notícias de que sua patrona, então viúva, se encontrava "reduzida a estado de necessidade", lhe "socorreu enquanto foi viva". Fato recente, conhecido por diversas pessoas no Recife, inclusive pelo governador da capitania à época, o mesmo conde de Povolide que governava a Bahia no momento de sua prisão. ${ }^{15}$

\footnotetext{
João de Oliveira, no qual pede lhe sejam restituídos os escravos e bens, que injustamente lhe haviam sequestrado, 27/07/1779.

${ }^{14}$ As ordenações filipinas previam que o forro deveria prestar gratidão e deferência aos seus antigos senhores e seus herdeiros sob pena de reescravização. O patrono poderia a qualquer momento revogar a alforria alegando ingratidão caso o forro lhe cometesse injúria em juízo ou em público, atentasse contra sua vida ou de seus herdeiros e até mesmo prejudicasse sua fazenda e negócios. Ver Livro IV, Título LXIII, Ordenações Filipinas. Ed. fac-similar da $14^{\mathrm{a}}$ Ed., segundo a primeira, de 1603, e a nona, de Coimbra, de 1821/ por Cândido Mendes de Almeida, Brasília: Senado Federal, Conselho Editorial, 2004, pp. 863-867.

${ }^{15} \mathrm{O}$ conde de Povolide administrou Pernambuco entre os anos de 1767 e 1769, sendo em seguida nomeado governador da Capitania da Bahia. Ver: AHU, ACL, CU, 015 Coleção Pernambuco-Avulsos, Cx. 105, D. 8108. Decreto do rei D. José I nomeando o conde de Povolide para o cargo de governador e capitão-general da capitania de Pernambuco, [Luís José da Cunha Grão Ataíde e Melo], por tempo de três anos, 14/08/1767. AHU, ACL, CU, 005-01 Bahia - Coleção Eduardo Castro e Almeida, Cx. 43, D. 8041-804, Carta do vicerei e capitão-general do Brasil, conde de Atouguia, Luís Peregrino de Ataíde ao rei [D. João V] remetendo a cópia do termo da sua posse no governo-geral, 20/03/1750. AHU, ACL, CU, 005 Coleção Bahia Avulsos, Cx. 163, D. 12402, Carta patente do governador da Bahia, conde de Povolide, José da Cunha e Ataíde a Manuel Gomes da Silva, nomeando-o capitão de Infantaria da Ordenança do Regimento da vila de Jaguaripe, 30/10;/1769.
}

Revista da ABPN • v. 12, n. Ed. Especial - Caderno Temático: "Africanos, escravizados, libertos biografias, imagens e experiências atlânticas” • agosto de 2020, p. 113-139 
Diante das escassezes de detalhes sobre os seus primeiros anos na Costa da Mina e também sobre como se tornou cabeceira nos portos negreiros, suponho, como havia dito anteriormente, que muito antes de se instalar e "militar como cabeceira", João de Oliveira passou um tempo trabalhando como marinheiro em embarcações negreiras. A familiaridade com os costumes - africanos e europeus -, bem como com a língua portuguesa, a fon e/ou ioruba contribuíram em seu aprendizado sobre os assuntos do tráfico. Ao afirmar, portanto, que vivia na Costa da Mina há 37 para 38 anos, talvez aí incluísse o período em que estava envolvido no tráfico transatlântico, indo e vindo de uma costa a outra, e não necessariamente residindo na África. Por conta disso, não é improcedente conjecturar que o indivíduo que abriu Porto Novo para o tráfico baiano fosse o mesmo João de Oliveira que, em 1738, denunciou junto a Ouvidoria Geral do Crime de Salvador o capitão da galera $N^{a} S^{a} d a$ Vida $e$ $S t^{\circ}$ Antônio, Pedro Gomes Caldeyra, por tê-lo “açoitado com correias nas nádegas” durante o retorno da viagem à Costa da $\mathrm{Mina}^{16}$.

Encabeçar uma denúncia de tal monta era algo bastante audacioso para um marinheiro, preto e liberto. Altivez e audácia também circundaram outros momentos da trajetória de João de Oliveira. Logo, é razoável supor que as arbitrariedades e violências comumente vivenciadas pelos libertos na América portuguesa tenham pesado na decisão do cabeceira de se instalar definitivamente na costa africana. Tudo isso se somou a uma conjuntura favorável de expansão do tráfico negreiro para outros portos da região, possibilitando o lucro, bem como a aquisição de prestígio na Costa da Mina.

A prisão de João de Oliveira - acusado pelo provedor da alfândega, Rodrigo da Costa Almeida, de concorrer com contrabando de tecidos vindos a bordo da corveta $N^{a} S^{a} d a$ Conceição São José e Almas - ocorreu num momento de cerco ao comércio ilícito de fazendas europeias oriundas da Costa da Mina. ${ }^{17}$ No final da década de 1760, ainda durante o governo do conde de Azambuja, as autoridades coloniais alarmaram-se com o contrabando de tecidos realizado em navios negreiros. O conde de Povolide, que havia assumido o governo da Bahia em 11 de outubro de 1770, buscou apertar o cerco às embarcações

\footnotetext{
${ }^{16}$ Arquivo Público do Estado da Bahia, doravante APEB, Seção Colonial/Provincial, Maço 515, fl 218, Livro de Alvarás e Provisões do Tribunal da Relação, 1738-1739.

${ }^{17}$ Verger chamou atenção de como a prisão de João de Oliveira inseria-se num contexto de repressão ao contrabando de tecidos feito pelos navios negreiros que comercializavam na Costa da Mina, cf. VERGER, (1987, p. 112; 1992, p 11).
}

Revista da ABPN • v. 12, n. Ed. Especial - Caderno Temático: "Africanos, escravizados, libertos biografias, imagens e experiências atlânticas” • agosto de 2020, p. 113-139 
oriundas da Costa da Mina suspeitas de contrabando de fazendas. ${ }^{18}$ Para tal, autorizou, por meio de portaria de 10 de maio de 1770 , o provedor da alfândega a abrir devassa sobre a corveta $N^{a} S^{a}$ da Conceição São José e Almas. A embarcação havia aportado na Baía de Todos-os-Santos dois dias antes, vinda da Costa da Mina, trazendo entre os seus passageiros João de Oliveira. ${ }^{19}$

A devassa teve início em 21 de maio, quando foram ouvidas as primeiras testemunhas. No total, foram 31 depoentes, entre eles os dois soldados e o sargento da Fortaleza do Mar que estiveram a bordo da corveta examinando sua carga, bem como o patrão-mor dos estaleiros reais da Ribeira, os prisioneiros das Galés que remaram o escaler do forte até a embarcação, além de pessoas que tiveram notícias sobre a chegada da corveta com contrabando. De acordo com as testemunhas, João de Oliveira havia, junto com o piloto da embarcação, contribuído com o suborno pago aos soldados e a um sargento do Forte do Mar para garantir o descarregamento de fazendas sem passar pela alfândega. Oliveira negou a acusação, afirmando que sequer vira o sargento ou os soldados a bordo da corveta. Disse, ainda, desconhecer se a embarcação trazia algum escravo fora de sua arqueação ou alguma fazenda, exceto dois maços que lhe pertenciam e 23 panos da costa "para seu gasto". ${ }^{20}$

Além desses tecidos, João Oliveira embarcou na corveta 118 escravos (75 do sexo masculino e 43 do feminino $)^{21}$ e duas “crias de peito". Conforme estimativas, a média de cativos transportada, ao longo do Setecentos, por uma corveta girava em torno de 300 africanos escravizados. Levando isso em consideração, João de Oliveira, sozinho, provavelmente dispunha de $40 \%$ da carga de escravos da corveta $N^{a} S^{a}$ da Conceição São

\footnotetext{
${ }^{18}$ Sobre a posse do conde de Povolide ao governo da Capitania da Bahia ver: AHU, ACL, CU, 005-01 Bahia - Coleção Eduardo Castro e Almeida, Cx.44, D. 8108, Ofício do governador, capitão general, conde de Povolide [Luiz José da Cunha Grã Ataide e Melo] sobre sua chegada à Bahia no dia dez, a tomada de posse no dia seguinte, e a partida do marquês do Lavradio para o Rio de Janeiro, no dia catorze, 15/10/1769. 19 APEB - Seção Colonial/Provincial, Portarias, Maço 467 (1767-1772), fl. 269v-270, Portaria do governador conde de Povolide, ordenando ao provedor da alfândega a abertura de uma devassa sobre o extraviu de fazendas que houve na chegada da última embarcação da Costa da Mina, 10/05/1770.
}

${ }^{20}$ A devassa consta na documentação sobre João de Oliveira, cf. AHU, ACL, CU, 005-01 Bahia - Coleção Eduardo Castro e Almeida, Cx. 44, D. 8249, Auto de devassa que se procedeu dos extravios e contrabandos feitos na chegada da corveta $N^{a} S^{a}$ da Conceição e Almas, de que é capitão Manuel de Sousa Coelho e senhorio Jacinto José coelho, vinda da Costa da Mina. Bahia, 21 /05/1770.

21 A princípio, haviam sido computados 122 escravos, que foram encaminhados à cadeia pública no momento da apreensão. Pouco tempo depois, no entanto, ficou esclarecido que quatro dos supostos escravos eram, na verdade, embaixadores do rei de Onim.

Revista da ABPN • v. 12, n. Ed. Especial - Caderno Temático: "Africanos, escravizados, libertos biografias, imagens e experiências atlânticas" • agosto de 2020, p. 113-139 
José e Almas. (OSÓRIO, 2016, pp. 25-38). Ademais, o liberto trouxe consigo 821\$825 réis em dinheiro de contado, mais $104 \$ 985$ réis em prata, quatro mil réis e vinte patacas em ouro, bem como 709\$200 réis em moedas de ouro e 7\$640 réis em moedas de cobre. Somavam-se ainda vários objetos pessoais, entre eles crucifixos e imagens de $\mathrm{N}^{\mathrm{a}} \mathrm{S}^{\mathrm{a}}$ da Conceição, talheres de prata, utensílios de louça, prata e cobre e móveis de jacarandá. Os cativos representavam o principal capital amealhado pelo cabeceira para passar seus últimos dias na Bahia, com os quais pretendia "tratar, dispor, vender e se alimentar com o seu produto". Certamente, utilizaria alguns no trabalho doméstico e outros no serviço de "ganho", do qual poderia obter bom lucro. (SOUZA, 2010). É possível que desejasse comercializá-los não apenas no mercado baiano, mas também enviá-los para outras capitanias, como Pernambuco, onde havia vivido.

De acordo com a descrição feita no termo de avaliação dos seus bens, cada cativo, "por ser a maior parte deles de maior idade, e outros crias, filhos dos mesmos", foi estimado "uns por outros" em 50\$000. As escravas, por sua vez, também possuíam idade avançada, sendo avaliadas em 40\$000, totalizando um capital de 4:690\$000 réis. Preço bem abaixo do valor que escravos boçais da Costa da Mina comumente eram vendidos na praça da Bahia que, à época, partiam de $130 \$ 000$ podendo chegar a $200 \$ 000$ mil réis. ${ }^{22}$

Levando-se em consideração a avaliação feita sobre os cativos, o mais provável é que estes não se encontrassem exatamente no perfil mais desejado pelo mercado escravista baiano, o qual apreciava homens jovens. Talvez esses escravos tivessem sido adquiridos pelo liberto há um certo tempo, daí muitos terem idade avançada e outros serem filhos pequenos destes. Formariam, então, a escravaria pessoal do cabeceira, uma vez que a posse de um grande séquito de escravos era sinônimo de poder e prestígio nas duas margens do Atlântico. (LAW, 1991, pp.136-137). De outra forma, pode-se estar falando de cativos oriundos de lotes de refugo, compostos por famílias vítimas de razias, cujos membros não jovens teriam sido rejeitados pelos capitães negreiros na Costa. O liberto, no entanto, poderia ter vislumbrado neles uma oportunidade de negócio, comprando-os por preço bem abaixo do mercado, pouco antes de embarcar de volta à Bahia.

\footnotetext{
${ }^{22}$ AHU, CU, 070 São Tomé, Cx 09, D. 83, Carta de Antônio Marques Gomes ao rei de Portugal [d. José] sobre a situação do comércio de escravos na Costa da Mina, as ações dos holandeses no sequestro de navios e na obrigatoriedade dos navios de nação portuguesa de lhe pagarem as "dachas" para negociarem na Costa da Mina, 30/12/1756.
}

Revista da ABPN • v. 12, n. Ed. Especial - Caderno Temático: "Africanos, escravizados, libertos biografias, imagens e experiências atlânticas" • agosto de 2020, p. 113-139 
Porém, com o sequestro dos seus bens e envio de seus escravos para a insalubre cadeia pública, o liberto temia a perda de alguns ou mesmo de toda a escravaria, o que o levaria a "perecer a necessidade". Apelando para a benevolência régia, argumentou que se isto ocorresse, se veria obrigado a "voltar a viver entre o paganismo". Ou seja, seria forçado a retornar à costa africana para mais uma vez engajar-se no tráfico transatlântico depois de tantos anos de serviço à nação portuguesa. Porém, àquela altura da vida, dificilmente conseguiria amealhar tamanha fortuna, correspondente a mais de 3.600 arrobas de açúcar branco, equivalente à produtividade média anual de um grande engenho. (SCHWARTZ, 1988, pp. 150 e 400-401).

João de Oliveira, para se esquivar das acusações, argumentou não ter concorrido com a introdução de fazendas sem o pagamento de direitos, nem poderia estar "ciente" do ocorrido, uma vez que tinha "total ignorância das leis e estilos do país". No auto de perguntas que lhe foi feito durante a devassa, respondeu ignorar o motivo de sua prisão. Apesar de pouco consistente, pois alegava inocência por ignorância, este argumento foi endossado pelos traficantes baianos e pelo próprio governador em atestado e ofício que se seguiram anexo ao requerimento do suplicante. Ambos solicitavam a absolvição do liberto. Embora o governador admitisse que a devassa apontava para culpabilidade do cabeceira, a investigação oferecia apenas uma "pequena prova" se comparada aos "bons serviços" prestados por ele aos vassalos da Coroa portuguesa.

$\mathrm{O}$ aval de grandes negociantes e do conde de Povolide contribuiu para o acolhimento da súplica de João de Oliveira junto ao rei d. José. Os bens do liberto foram devolvidos em 18 de julho de 1770, pouco mais de dois meses após a sua chegada à Bahia. De acordo com o auto de perguntas que lhe foi feito durante a devassa, ele havia se instalado numa residência alugada "ao diante da Igreja do Pilar", localizada na freguesia do Santíssimo Sacramento do Pilar. Provavelmente, nesta casa abrigou, se não todos, pelo menos parte dos 104 escravos que lhes foram entregues quando da restituição dos seus bens, sendo que dez faleceram na cadeia, dois teriam sido doados a uma irmandade pernambucana e quatro eram, na verdade, emissários do rei de Onim. Após esse episódio, não há mais notícias sobre João de Oliveira na documentação das autoridades coloniais. É provável, no entanto, que estes não tenham sido os últimos escravizados que o liberto importou da Costa da Mina. Afinal, a vinda para Bahia para "viver entre os cristãos" não

Revista da ABPN • v. 12, n. Ed. Especial - Caderno Temático: "Africanos, escravizados, libertos biografias, imagens e experiências atlânticas” • agosto de 2020, p. 113-139 
significaria necessariamente que estivesse encerrando sua carreira no tráfico transatlântico de africanos.

\section{JOÃO DE OLIVEIRA: UM SENHOR DE ESCRAVOS}

Ao analisar os assentos de batismo da freguesia do Santíssimo Sacramento do Pilar, local escolhido pela nossa personagem para residir, foi encontrado um senhor denominado capitão João de Oliveira, que batizou vários escravos oriundos da Costa da Mina, especificamente, na década de 1770. Ao todo, dezesseis africanos adultos recémdesembarcados receberam os santos óleos em quatro ocasiões. O batismo da maioria deles ocorreu em conjunto, em blocos de dois, cinco e nove indivíduos, típico de quem adquiria escravos diretamente na costa da África ou em lote, logo após o desembarque, e visava, muitas vezes, revende-los no interior da capitania ou para outras regiões da colônia.

Nos livros de banguê da Santa Casa de Misericórdia da Bahia, onde a instituição registrava os sepultamentos de escravos, presos das galés e indigentes, consta também um senhor denominado capitão João de Oliveira. Este teria sido responsável pelo enterro de doze cativos, entre os anos de 1771 e 1778, sendo cinco mulheres e sete homens. Apenas metade teve a origem apontada, três jejes e três minas. ${ }^{23}$ Provavelmente, as duas séries documentais se referem ao mesmo indivíduo e, é quase certo, que se trate do cabeceira João de Oliveira.

Há uma coincidência cronológica e espacial, que fundamenta essa suposição, uma vez que ambos os registros ocorreram entre 1771 e 1778 e o senhor dos cativos relacionados era residente na freguesia do Pilar, onde o cabeceira teria se instalado ao chegar em Salvador, conforme seu depoimento. É provável que o título de cabeceira, nas terras baianas, tenha sido adaptado para capitão. O que não lhe alteraria do todo modo o sentido, pois, nos portos da Costa da Mina, o cabeceira dirigia os interesses do rei africano nas negociações com comerciantes europeus e locais, sendo uma espécie de capitão. Da mesma forma, o oficial que dirigia o navio negreiro, cujo título era capitão, respondia pelos interesses do senhorio da embarcação e de seus investidores.

Outra possibilidade, seria João de Oliveira ter ingressado no Terço de Henrique Dias, também conhecido como Terço dos Homens Pretos, corpo de milícia formado por libertos

\footnotetext{
${ }^{23}$ Arquivo da Santa Casa de Misericórdia da Bahia, doravante ASCMB, Maços 1261 e 1262, Livro de Banguê, 1764-1772 e 1772-1780. O banguê foi criado pela Misericórdia, em 1693, visando garantir um enterro cristão a escravos e indigentes, evitando o abandono dos corpos nas ruas ou o seu sepultamento em covas rasas. Sobre a instituição do banguê pela Santa Casa ver: RUSSEL WOOD, (1981).
}

Revista da ABPN • v. 12, n. Ed. Especial - Caderno Temático: "Africanos, escravizados, libertos biografias, imagens e experiências atlânticas” • agosto de 2020, p. 113-139 
africanos e crioulos, sendo comumente utilizado por estes como espaço em que se poderia obter algum prestígio e reconhecimento quanto a sua liberdade no mundo dos brancos. Desde os tempos no Recife, o liberto africano mantinha relações com esse agrupamento militar, tendo auxiliado seus membros, bem como a irmandade a qual eram ligados, com donativos para a construção da Igreja de $\mathrm{N}^{\mathrm{a}} \mathrm{S}^{\mathrm{a}}$ da Conceição dos Militares, como já foi dito, onde os libertos do Terço esperavam poder ser sepultados. Nesse caso, por ostentar boas relações com renomados negociantes da Bahia, ter uma condição econômica distinta em relação aos demais libertos, João de Oliveira teria conseguido ingressar no Terço dos Homens Pretos como oficial, desfrutando o título de capitão. Logo, volto a repetir, é plausível que o capitão e o cabeceira João de Oliveira sejam a mesma personagem.

O esquife da Santa Casa de Misericórdia era comumente utilizado para o sepultamento de africanos recém desembarcados, chamados de boçais, que faleciam dias ou semanas após o desembarque, devido a debilidade causada pela viagem. Alguns padeciam antes de receberem o batismo católico e, por isso, não apresentavam nome branco cristão nos registros. Dos doze africanos sepultados pelo capitão João de Oliveira, um deles certamente era recémchegado, pois não possuía nome, apenas a descrição "um negro jeje". Além disso, este cativo não foi sepultado no adro de uma igreja, mas no cemitério do Campo da Pólvora, fora do terreno sagrado do catolicismo, como normalmente se fazia com indivíduos não batizados. ${ }^{24}$

Além desses registros, o banguê lança mais uma pista que se aproxima de João de Oliveira. Em 18 de abril de 1767, três anos antes do cabeceira retornar à Cidade da Bahia, ocorreu as exéquias de Rosa, moradora na ladeira da Preguiça, escrava pertencente a Silvestre. Este, por sua vez, era escravo de "João de Oliveira que se achava na Costa da Mina". ${ }^{25}$ É lícito supor que seja o cabeceira, posto que, como foi dito, poucos anos antes dele voltar à Salvador, havia enviado escravos para o Recife para socorrer sua patrona, e contribuir com a construção da Igreja de $\mathrm{N}^{\mathrm{a}} \mathrm{S}^{\mathrm{a}}$ da Conceição dos Militares. Portanto, se encaminhava escravos para o Brasil por caridade, é provável que também o fizesse para investir. Talvez dispusesse de um ou mais cativos empregados em Salvador, subordinados a algum agente comercial de sua confiança. Quiçá, estes escravizados estivessem empregados no ganho ou

\footnotetext{
${ }^{24}$ ASCMB, Livro de Banguê, Maço 1262, Registro do sepultamento de um negro jeje, 17/07/1772.

${ }^{25}$ ASCMB, Livro de Banguê, maço 1262, Sepultamento de Valério mina, 20/01/1778. ASCMB, Livro de Banguê, Maço 1261, fl 110v, Sepultamento de Rosa, 18/04/1767. Este documento também foi citado por XIMENES, (2012, pp. 206-207).
}

Revista da ABPN • v. 12, n. Ed. Especial - Caderno Temático: "Africanos, 
em alguma atividade relacionada ao tráfico de africanos, comércio que, certamente, o senhor de Silvestre - independentemente de ser ou não a personagem em questão - estava envolvido, já que se encontrava na Costa da Mina.

Manter um escravizado na outra margem do Atlântico era característico de um proprietário que jogava com a autonomia e com o poder da ideologia senhorial para assegurar a efetiva exploração de sua propriedade, mesmo considerando que o cativo poderia estar sobre o controle de um representante de seu senhor. Os escravizados urbanos, devido às peculiaridades de suas atividades, muitas vezes usufruíam de relativa independência para morar e trabalhar, o que possibilitava a alguns deles a formação de um pecúlio, como fez Silvestre. (REIS 2003, 2019) O diferencial neste caso foi Silvestre ter transformado suas economias em propriedade escrava, correndo todos os riscos deste negócio, inclusive o da perda do investimento por conta de fuga ou falecimento, como acabou ocorrendo. Embora não fosse algo disseminado, a existência de escravos senhores de escravos não era um fenômeno totalmente desconhecido na Cidade da Bahia e tinha uma relação direta com o tráfico transatlântico de africanos. (ALMEIDA, 2018; REIS, 2014; SOUZA, 2018). Caso o dono de Silvestre seja o mesmo cabeceira João de Oliveira, é interessante notar que este, enquanto senhor, reproduziu com o seu cativo uma relação de exploração escravista baseada na autonomia, parecida com a qual foi submetido enquanto escravizado.

Nos registros paroquiais, o primeiro assento de batismo de um escravo do capitão João de Oliveira data de $1^{\circ}$ de janeiro de 1772, quando Manoel mina recebeu o sacramento, tendo como padrinho o preto forro José Fernando Simão Ribeiro. Em 3 de março de 1773, foi a vez de Vitorianna e Luiza, ambas minas. O padrinho da primeira foi o preto forro e mestre barbeiro Francisco Nunes de Morais. A segunda foi apadrinhada por Francisco, escravo do reverendo padre mestre Manoel Maciel Almeida, morador na freguesia da Sé.

No terceiro assento, registrado em 14 de novembro de 1773, foram batizados nove africanos minas, a saber: Francisco, José, Ventura, Valério, Matheus, Joana, Rita, Susana e Roza. Novamente, o padrinho seria um preto forro, Lourenço Fernandes Monteiro, casado com Rita, preta forra, arrolada como madrinha no registro. $\mathrm{O}$ último assento referente ao capitão, localizado nesta série, data de 16 de junho de 1778 - mesmo ano do último registro do banguê. Neste dia, levou Antonia, Anna, Domingas e Engracia, todas

Revista da ABPN • v. 12, n. Ed. Especial - Caderno Temático: "Africanos, escravizados, libertos biografias, imagens e experiências atlânticas" • agosto de 2020, p. $113-139$ 
de nação nagô, para receberem os santos óleos. Os padrinhos foram Silvestre mina e José mina, escravos do próprio capitão João de Oliveira. ${ }^{26}$

Os assentos e os registros no banguê não mencionam se o capitão João de Oliveira era preto forro. Os escrivães da Santa Casa não costumavam informar a cor ou condição jurídica dos senhores que sepultavam seus cativos. Já o vigário Pedro Barboza Godim - responsável pelo livro em que constam os assentos dos escravos do capitão João de Oliveira e pelo registro de $68 \%$ dos batismos da freguesia do Pilar na segunda metade do Setecentos - em comparação com outros seculares da freguesia, era cuidadoso em suas anotações. Godim chegava a escrever o endereço dos senhores que levavam seus escravos para batizar e dos padrinhos que o acompanhavam, algo pouco comum. No entanto, o padre, assim como outros eclesiásticos, costumava omitir a cor dos senhores quando se tratava de pessoas brancas e apenas apontar quando do contrário. Em 87\% dos registros feitos por Godim ocorreu essa situação. Isto não significa, contudo, que neste grupo não existissem omissões sobre senhores não-brancos. A condição jurídica e a origem do capitão João de Oliveira dificilmente teriam passado em branco pelo vigário, muito menos em preto, a não ser intencionalmente. Logo não duvido que possa ter havido um silêncio por parte do vigário acerca da origem africana do capitão João de Oliveira, talvez até a pedido do próprio. ${ }^{27}$

O fato de não haver mais dados sobre escravos pertencentes ao liberto em ambas as fontes, após 1778, faz supor que ele talvez tenha falecido - afinal já passava dos 70 anos ou tenha definitivamente encerrado seus negócios na África. Ademais, cabe destacar que todos os cativos pertencentes ao capitão, cuja origem foi apontada, eram oriundos dos portos da Costa da Mina. Embora esta região tivesse sido privilegiada pelo tráfico baiano, Angola respondia por, no mínimo, 30\% das importações de mão de obra escravizada feitas pela capitania. Os assentos de batismo e os registros do banguê indicam que João de Oliveira continuou engajado no tráfico transatlântico após o seu retorno da África, fazendo, ainda em

\footnotetext{
${ }^{26}$ Arquivo da Cúria Metropolitana de Salvador, doravante ACMS, Livro de Registro de Batismos da Freguesia do Santíssimo Sacramento do Pilar (1771-1783), fls 4v, 28v, 42v, 109, Registro de batismo de Manoel mina, 06/01/1772; Registro de batismo de Vitoriana mina e Luzia mina, 03/03/1773; Registro de batismo dos africanos minas Francisco, José, Ventura, Valério, Matheus, Joana, Rita, Susana e Roza, 14/11/1773; Registro de batismo das africanas nagô Antonia, Anna, Domingas e Engracia, 16/06/1778.

${ }^{27}$ Para o livro de batismo em que constam os assentos dos cativos do capitão João de Oliveira ver: ACMS, Livro de Registro de Batismos da Freguesia do Santíssimo Sacramento do Pilar (1771-1783). Os demais livros disponíveis sobre esta freguesia, no século XVIII, referem-se aos seguintes períodos: 1760-1769, 1784-1790, 1790-1801
}

Revista da ABPN • v. 12, n. Ed. Especial - Caderno Temático: "Africanos, escravizados, libertos biografias, imagens e experiências atlânticas" • agosto de 2020, p. $113-139$ 
terras baianas, do comércio de pessoas seu meio de vida. Desfrutava de um espaço privilegiado para isso. Certamente, manteve as relações mercantis com comerciantes na Costa da Mina, com proprietários de embarcações e capitães de navios negreiros, talvez até investisse diretamente em algumas carregações. A escolha de deixar para trás "povoações pagãs" e passar seus últimos dias em terras católicas e nelas ser sepultado, portanto, não significou que desejasse apartar-se dos negócios do tráfico e da escravidão.

A riqueza conquistada após quase 40 anos trabalhando no comércio negreiro assegurou a João de Oliveira não apenas a liberdade, mas também a formação de significativo pecúlio. A escravaria que possuía ao desembarcar correspondia à quantidade média de cativos de um engenho de grande porte. Da mesma forma, caso os vendessem pelo preço constante na avaliação, o seu produto, 5:090\$000 réis, equivaleria ao valor da safra anual de açúcar de um grande engenho (SCHWARTZ, 1988, pp. 150 e 400-401). Dentro das possibilidades de prestígio e riqueza passíveis de serem auferidas pela maioria dos libertos na América portuguesa, João de Oliveira era de longe um exemplo de sucesso.

A fortuna amealhada pelo cabeceira e o respeito adquirido em meio a brancos e ricos comerciantes na Bahia causavam espanto, tanto entre as pessoas de origem africana quanto europeia. Se sua presença despertava a inveja de uns, talvez, ascendesse em outros as possíveis expectativas de vida após a obtenção da manumissão. Ou seja, seu retorno a Salvador como um bem-sucedido cabeceira e colaborador dos vassalos lusitanos na Costa da Mina possuía um importante papel ideológico para a escravidão na América portuguesa. Isto porque, em meio à população de origem africana, fortalecia a ideia de que "bons serviços", trabalho árduo e lealdade a Coroa portuguesa poderiam proporcionar a superação da escravidão e, quiçá, da pobreza. ${ }^{28}$

Ao retornar à Bahia e experimentar a prisão e sequestro de seus bens como contrabandista, João de Oliveira percebeu o quanto a sua liberdade dependia das boas relações construídas no mundo Atlântico. Ou seja, ele somente foi solto e obteve a restituição de seus bens graças ao reconhecimento desfrutado em meio aos traficantes da praça da Bahia. Quiçá, caso se trate do mesmo indivíduo, ao ver sua liberdade e fortuna postas em xeque, João de Oliveira tivesse lembrado do processo contra Pedro Gomes Caldeyra décadas atrás,

\footnotetext{
${ }^{28}$ Sobre a ideologia senhorial em torno da manumissão e da liberdade, ver MATTOSO, 1990, pp. 1762018; SCHWARTZ, 2001, pp. 171-218; CUNHA, 1986, pp. 123-144; CHALHOUB, 1990, pp. 95-107; REIS, 2010, pp. 113-132).
}

Revista da ABPN • v. 12, n. Ed. Especial - Caderno Temático: "Africanos, escravizados, libertos biografias, imagens e experiências atlânticas” • agosto de 2020, p. 113-139 
recordando que em terra de branco a origem africana é determinante para se estar suscetível a violências e arbitrariedades.

Partindo desta experiência, é possível que o cabeceira tenha entendido que, para resguardar a sua liberdade e os seus negócios, era importante estar entrelaçado por sólida rede de solidariedade, ter um séquito de dependentes, desfrutar de prestígio e confiança, não apenas no mundo dos brancos, mas também na comunidade africana. Talvez, por isso, não demorou em tecer relações em meio aos libertos africanos moradores na freguesia do Pilar, através do apadrinhamento de escravos.

De acordo com os registros paroquiais, nas residências localizadas junto ao forte de São Francisco, na freguesia do Pilar, havia uma comunidade de pretos forros com os quais ao capitão João de Oliveira teceu fortes relações. Residiam na localidade, o liberto jeje Francisco Nunes de Morais que, como foi visto, apadrinhou uma cativa do cabeceira. Morais, além de mestre barbeiro, costumava ensinar este ofício para africanos boçais em sua casa e foi senhor de, pelo menos, 19 cativos. ${ }^{29}$ Um escravizado barbeiro poderia proporcionar bons lucros ao seu senhor, que poderia empregá-lo tanto nas ruas da cidade, quanto a bordo de navios negreiros, onde eles eram essenciais para os cuidados da tripulação e da carga humana. (SOUZA, 2018, p. 260. PARÉS, 2014)

Próximos ao capitão, havia ainda o casal de libertos Lourenço Fernandes Monteiro e Rita, já mencionados em um registro de batismo anterior, e o casal de pretos forros Lourenço Gomes de Oliveira e Izabel de Oliveira, residentes numa casa junto ao Forte de São Francisco. Estes dois, no dia 9 de junho de 1780, batizaram os escravizados Joaquina, preta mina, e Luis, "rapaz" mina. O padrinho de ambos foi o crioulo forro João de Oliveira, filho natural da africana Izabel de Oliveira. Ou seja, o padrinho batizou os cativos de sua mãe. Com tal sobrenome e morando no mesmo sítio em que o cabeceira viveu, é possível que o casal e o crioulo forro fossem ex-escravos do capitão João de Oliveira. Se assim for, adotaram seu sobrenome após alcançarem a alforria e o filho de Izabel foi batizado com o mesmo nome de seu antigo senhor. Talvez, ele fosse o pai da criança ou a homenagem fosse expressão de gratidão, quiçá pela promessa de libertar ela e seu filho, ou mesmo por imposição senhorial.

A rede que entrelaçava africanos oriundos da Costa da Mina em um pequeno espaço da freguesia do Pilar não se encerrava por aí. Os escravos de Izabel de Oliveira, Joaquina

\footnotetext{
${ }^{29}$ Livro de Batismos da Freguesia do Santíssimo Sacramento do Pilar, 1790-1781, 05/12/1794, ACMS, fl 89.
}

Revista da ABPN • v. 12, n. Ed. Especial - Caderno Temático: "Africanos, escravizados, libertos biografias, imagens e experiências atlânticas” • agosto de 2020, p. 113-139 
mina e Luis mina, dispuseram de uma madrinha durante o sacramento, o que é digno de nota, pois a presença de madrinhas era pouco importante nos batismos da época. (SOUZA, 2018, p. 177) Joaquina teve como madrinha Anastácia, também escrava de Izabel de Oliveira. Provavelmente, caberia a Anastácia, além de zelar pela fé e comportamento cristão de sua afilhada, ser responsável por lhe ensinar o serviço e os costumes da nova terra, ou seja, ladinizá-la. A madrinha de Luis, por sua vez, foi a preta forra Thereza de Oliveira, moradora na mesma casa em que residia Lourenço Gomes de Oliveira e Izabel de Oliveira e portadora do mesmo sobrenome. Coincidência que nos leva a crer que Thereza tenha sido companheira de cativeiro do casal e, enquanto liberta, seguia dividindo com eles a moradia. ${ }^{30}$ É possível, inclusive, que todos esses libertos fossem ex-escravos do capitão João de Oliveira. Quiçá teriam vindo juntos com ele a bordo da corveta $N^{a} S^{a}$ da Conceição São José e Almas e permaneceram quase dois meses presos na cadeia pública logo após o desembarque na Bahia. Desta maneira, os laços que os uniam extrapolavam o convívio em cativeiro, remontavam a travessia atlântica e/ou a origens étnicas comuns, tornando-os malungos (SLENES, 1991/1992, pp. 48-67).

Os assentos paroquiais, contudo, não permitem elucidar maiores detalhes sobre a vida desses libertos e seus cativos. Pode-se supor que atuassem no ganho de rua, o que lhes teria permitido obter os recursos necessários para a compra de alforria. Quiçá, a manumissão tivesse sido gratuita ou condicionada a acompanhar seu senhor até a morte. Uma vez libertos, os ex-escravos de João de Oliveira teriam adquirido cativos para empregar nas atividades urbanas, principalmente, relacionadas ao transporte, ao comércio e aos ofícios especializados. Vale destacar, porém, que os cativos batizados por Izabel Oliveira e Lourenço Gomes de Oliveira eram jovens africanos oriundos da Costa da Mina, talvez fruto de pequenos investimentos feitos na aquisição direta de escravos na Costa da Mina, tal qual o fazia o capitão João de Oliveira.

Logo estes libertos, incluindo o próprio cabeceira, obtinham, direta ou indiretamente, seus meios de vida por meio do comércio negreiro ou através da rede de negócios mobilizada por ele. O emprego de pequenos capitais no tráfico, a compra de tecidos contrabandeados da Costa da Mina para revender nas ruas de Salvador ou o aluguel de cativos para embarcações negreiras, principalmente como barbeiros, constituíam-se em possibilidades reais de

\footnotetext{
${ }^{30}$ ACMS, Livro de Registro de Batismos da Freguesia do Santíssimo Sacramento do Pilar (1771-1783), fl 141, Registro de batismo de Joaquina mina, 09/06/1780.
}

Revista da ABPN • v. 12, n. Ed. Especial - Caderno Temático: "Africanos, escravizados, libertos biografias, imagens e experiências atlânticas” • agosto de 2020, p. 113-139 
investimento e lucro para alguns libertos. Pode-se afirmar, portanto, que o tráfico se disseminou de tal forma na economia da Cidade da Bahia que seus habitantes dificilmente conseguiam não orbitar em torno deste negócio.

João de Oliveira é uma das personagens que se inserem no quadro que Robin Law e Kristin Mann definiram como comunidade atlântica da Costa dos Escravos (que os portugueses denominavam Costa da Mina). Ao longo do século XVIII, mas principalmente no XIX, a região recebeu vários africanos libertos e seus descendentes oriundos das Américas, a maioria deles se engajou no tráfico de escravos. João de Oliveira, portanto, não foi o único africano retornado a estabelecer sólidas relações mercantis com o comércio transatlântico. Em 1780, Antônio Vaz Coelho se destacava como importante negociante em Porto Novo, sendo descrito como negro nascido no Brasil, que sabia ler, escrever e contar (LAW e MANN, 1999, pp. 307-334). Neste mesmo ano, tem-se notícia de que, em Ajudá, dom Jerônimo, cujo nome africano era Fruku, atuava como comerciante oficial do rei daomeano. De acordo com Akinjogbin, Fruku havia sido escravizado e vendido por Tegbessu a capitães negreiros que se dirigiam ao Brasil, em virtude de ele ser seu rival na linha sucessória do trono daomeano. Após 24 anos de cativeiro, quando Kpengla assumiu o poder, Fruku, então denominado dom Jerônimo, teria sido resgatado, tornando-se pessoa de destaque na corte do Daomé. (AKINJOGBIN, 1967, pp. 116 e 171-172; LAW e MANN, 1999, pp. 307-334; SILVA, 2003, pp. 119-120).

Vítima de escravização na África Ocidental, cuja rede alimentava o tráfico transatlântico de escravos, que se ligava a um sistema maior de produção de mão de obra e de commodities transcontinental, João de Oliveira terminou indo parar no Recife. Por muito pouco, poderia ter sido cativo nos canaviais da Zona da Mata pernambucana, nos engenhos do Recôncavo baiano, nas plantações da Jamaica, Virgínia, Saint-Domingue ou em qualquer outra cidade onde houvesse escravidão nas Américas. O acaso de ter ido parar no Recife e depois Salvador, como escravo de um investidor do tráfico, não explica totalmente a sua trajetória. O Atlântico escravista e a procura cada vez maior por mão de obra escravizada nas Américas proporcionaram as circunstâncias e oportunidades para que João de Oliveira fizesse do tráfico de escravos seu meio de vida. No momento em que pensava poder desfrutar seus últimos dias na Cidade da Bahia, de posse de uma significativa fortuna em cativos, viveu o infortúnio da prisão e ameaça de perder seus bens. Mais uma vez, foram os seus préstimos ao

Revista da ABPN • v. 12, n. Ed. Especial - Caderno Temático: "Africanos, escravizados, libertos biografias, imagens e experiências atlânticas” • agosto de 2020, p. 113-139 
comércio negreiro que o livraram da cadeia, tornando o tráfico, a escravidão e a liberdade elementos indissociáveis da sua trajetória.

\section{REFERÊNCIAS BIBLIOGRÁFICAS}

AKINJOGBIN, Isaac Adeagbo. Dahomey and Its Neighbours 1708-1818. London: Cambridge University Press: 1967.

ALMEIDA, Kátia Lorena Novais de. Escravos e libertos nas minas do Rio de Contas: Bahia, século XVIII. Salvador: EDUFBA: 2018.

CALDAS, José Antônio. Notícia Geral de toda essa Capitania da Bahia, desde o seu descobrimento até o presente ano de 1759. Edição fac-similar, Salvador: Tipografia Beneditina: 1951.

CHALHOUB. Sidney. Visões da Liberdade: uma história das últimas décadas da escravidão na Corte. São Paulo: Cia das Letras: 1990.

COSTA, Robson Pedrosa, A Ordem de São Bento e os escravos do Santo, Pernambuco, séculos XVIII e XIX. Tese (Doutorado em História), Universidade Federal de Pernambuco, Recife, PE, 2013.

CUNHA, Manuela Carneiro da, "Sobre os silêncios da lei. Lei costumeira e positiva nas alforrias de escravos no Brasil do século XIX”. Antropologia do Brasil: mito, história e etnicidade, São Paulo: Ed. Brasiliense/Edusp, 1986, pp. 123-144.

HICKS, Mary E. "João de Oliveira's Atlantic World: mobility and dislocation in Eighteenth-Century Brazil and the Bight of Benin", in AJE, Lawrence \& ARMSTRONG, Catherine: The Many Faces of Slavery: New Perspectives on Slave Ownership and Experiences in the Americas. Bloomsbury: Format: EPUB/MOBI eBook: 2019.

LAW, Robin e MANN Kristin, West Africa in the Atlantic Commmunity: the Case of the Slave Coast, William and Mary Quarterly, $3^{\mathrm{a}}$ Serie, vol 56, no2, 1999, pp. 307-334.

LAW, Robin. The Slave Coast of West África 1550-1750. The Impact of the Atlantic Slave on an African Society. Clarendon Press: Oxford,:1991. . The Oyo Empire c. 1600-c.1836. A West African Imperialism in the Era of the Atlantic Slave Trade. Clarendon Press: Oxford:1997. Ouidah. The Social History of a West African Slaving "Port" 1727-1892. Athens, Ohio: University Press: Oxford: James Currey, 2004

LESSA, Clado Ribeiro, Viagem de África em o Reino de Dahomé. Escrita pelo Padre Vicente Ferreira Pires no ano de 1800 e até o presente inédita. São Paulo: Brasiliana, Companhia Editora Nacional: 1957.

LINEBAUGH, Peter e REDIKER, Marcus. A hidra de muitas cabeças: marinheiros, escravos, plebeus e a história oculta do Atlântico revolucionário. São Paulo: Companhia das Letras: 2008.

MATTOSO, Katia M. de Queirós. Ser escravo no Brasil. 3a. São Paulo: Brasiliense: 1990.

Revista da ABPN • v. 12, n. Ed. Especial - Caderno Temático: "Africanos, escravizados, libertos biografias, imagens e experiências atlânticas" • agosto de 2020, p. $113-139$ 
OSÓRIO, Inês Marinho. O transporte de escravos no Atlântico: arqueação dos navios negreiros. Dissertação (Mestrado em História), Universidade Nova de Lisboa, Lisboa, PT, 2016.

PARÉS, Luís Nicolau. Milicianos, barbeiros e traficantes numa irmandade católica de africanos minas e jejes (Bahia, 1770-1830), Revista Tempo, vol 20, 2014, pp. 1-32.

REDIKER, Marcus. O navio negreiro: uma história humana. São Paulo: Companhia das Letras: 2011.

REIS, Isabel Cristina Ferreira dos. Breves reflexões acerca da historiografia sobre a família negra na sociedade escravista brasileira oitocentista, Revista da ABPN, vol. 1, nº 2, 2010, pp. 113-132.

REIS, João José. Rebelião Escrava no Brasil. A História do Levante dos Malês em 1835. - ed rev. e amp. São Paulo: Companhia das Letras: 2003. Letras, 2019.

Ganhadores: a greve negra de 1857 na Bahia. 1. ed. São Paulo: Companhia das

GOMES, Flávio dos Santos; CARVALHO, Marcus J M de. O Alufá Rufino: tráfico, escravidão e liberdade no Atlântico negro (c.1822-c.1853). São Paulo: Companhia das Letras: 2010.

. Domingos Sodré. Um sacerdote africano. São Paulo: Companhia das Letras: 2008.

. Escravos donos de escravos na Bahia Oitocentista. Texto inédito:2013.

. From Slave to Wealthy African Freedman: The Story of Manoel Joaquim Ricardo. In LINDSAY, Lisa A. and SWEET, John Wood (eds.) Biography and the Black Atlantic. Philadelphia, University of Pennsylvania Press, 2014, pp. 131-145;

. De escravo a rico liberto: a trajetória do africano Manoel Joaquim Ricardo na Bahia Oitocentista, Revista de História da USP, nº 174, 2016, pp. 15-68.

RIBEIRO, Alexandre Vieira. $O$ tráfico transatlântico de escravos e a praça mercantil de Salvador c.1680-c.1830. Dissertação (Mestrado em História), Universidade Federal do Rio de Janeiro, Rio de Janeiro-RJ, 2005.

RODRIGUES, Jaime. De costa a costa: escravos, marinheiros e intermediários do tráfico negreiro de Angola para o Rio de Janeiro (1780-1860). São Paulo: Companhia das Letras: 2005.

No mar e em terra: história e cultura de trabalhadores escravos e livres.São Paulo:

Alameda: 2016.

RUSSEL-WOOD, A. J. R. Fidalgos e Filantropos. A Santa Casa de Misericórdia na Bahia, 15501755, Brasília: Ed.UNB: 1981.

SAMPAIO, Gabriela dos Reis, Juca Rosa: um pai-de-santo na corte imperial. Rio de Janeiro: Arquivo Nacional: 2009.

SCHWARTZ, Stuart B. Segredos Internos: engenhos e escravos na sociedade colonial, 15501835. São Paulo: Companhia das Letras: 1988.

, Escravos, Roceiros e Rebeldes. Bauru - SP: EDUSC, 2001

SILVA, Alberto da Costa e, Um Rio chamado Atlântico: a África no Brasil e o Brasil na África. Rio de Janeiro: Nova Fronteira: Ed. UFRJ: 2003.

2004.

Francisco Félix de Souza, mercador de escravos, Rio de Janeiro: Nova Fronteira: EdUERJ:

Revista da ABPN • v. 12, n. Ed. Especial - Caderno Temático: "Africanos, escravizados, libertos biografias, imagens e experiências atlânticas" • agosto de 2020, p. 113-139 
SLENES, Robert. Malungu, ngoma vem! África coberta e descoberta no Brasil. Revista USP, $\mathrm{n}^{\circ} 12$, 1991/1992, p. 48-67.

SOUZA, Cândido Eugênio Domingues de. "Perseguidores da espécie humana": capitães negreiros da Cidade da Bahia na primeira metade do século XVIII", Dissertação, (Mestrado em História) Universidade Federal da Bahia, Salvador, BA, 2011.

SOUZA, Daniele Santos de. "Entre o serviço da casa e o ganho": escravidão em Salvador na primeira metade do século XVIII. Dissertação (Mestrado em História), Universidade Federal da Bahia, Salvador, BA, 2010.

. Tráfico, escravidão e liberdade na Bahia nos "anos de ouro" do comércio negreiro (c.1680-c.1790). Tese (Doutorado em História), Universidade Federal da Bahia, Salvador, BA, 2018.

SOUZA, Evergton Sales, "Une histoire de foi et de trafic dans l'Atlantique Sud au XVIIIe siècle: le cas de l'Africain João de Oliveira". Apresentação de Trabalho/Comunicação, in: Séminaires sur le Brésil colonial et l'Ancien Régime sous les Tropiques dans l'empire portugais EHESS, 2013.

SPARKS, Randy J. Where the Negroes Are Masters: An African Port in the Era of the Slave Trade. Cambridge: Massachusetts and Londres: Harvard University Press: 2014. . The Peopling of an African Slave Port: Annamaboe and the Atlantic World, Almanack, $\mathrm{n}^{\circ}$ 24, 2020.

VERGER, Pierre. Fluxo e Refluxo do tráfico de escravos entre o golfo do Benin e a Bahia de Todos os Santos: século XVII ao XIX. São Paulo: Corrupio: 1987.

Os libertos: sete caminhos na liberdade de escravos na Bahia no século XIX. São Paulo: Corrupio: 1992.

XIMENES, Cristiana Ferreira Lyrio. Bahia e Angola: redes comerciais e o tráfico de escravos 1750-1808, Tese (Doutorado em História) Universidade Federal Fluminense, Niterói, RJ, 2012.

Recebido em 01/07/2020

Aceito em: $23 / 07 / 2020$

Revista da ABPN • v. 12, n. Ed. Especial - Caderno Temático: "Africanos, escravizados, libertos biografias, imagens e experiências atlânticas" • agosto de 2020, p. 113-139 